\title{
On the Brink of Post-Democracy: Indonesia's Identity Politics in the Post-Truth Era
}

\author{
MADE YAYA SAWITRI, I NYOMAN WIRATMAJA \\ Faculty of Social and Political Science, Warmadewa University
}

\begin{abstract}
Summary
As a country with a diversity of languages, religions, ethnicities and cultures, Indonesia is particularly vulnerable to the hostile play of identity politics. Lies produced during the Post-Truth period exploit many emotional sentiments and provoke interest groups to act based on primordial impulses that support certain political interests. The negative turbulence related to identity politics due to the chaotic circulation of hoaxes and misinformation is feared to lead to a Post-Democratic situation. Taking the case study of the two most influential elections in Indonesia: the 2017 Jakarta provincial election and the 2019 presidential election, this paper will explore how the Post-Truth phenomenon incorporates the issue of identity politics to generate a Post-Democratic situation in Indonesia. Secondary data analysis from the news and social media will be employed to further explain how identity politics is distorted in the media, and how it can generate social and political turbulence.
\end{abstract}

Keywords: Post-Truth, Identity Politics, Post-Democracy, Indonesia

\section{Introduction}

Since the fall of Suharto's New Order regime in 1998, Indonesians have generally enjoyed greater freedom of expression. Millions of citizens use social media, from Facebook, Twitter, Instagram to WhatsApp, to share their views and opinions on a daily basis. The country is currently home to the fourth-highest number of Facebook users in the world. On average, these users spend 8 hours and 36 minutes online every day, making Indonesia the fifth most digitally active country behind the Philippines, Brazil, Thailand and Colombia (Wong, 2019). High Internet use and social media penetration was expected to bring digital empowerment in politics. People are supposed to be more connected and eager to participate in political discussion. However, social media also possess some disadvantages, such as the prob- 
lem of privacy, online radical group recruitment, and most importantly the proliferation of hoaxes and fake news.

In recent years, Indonesia has been struggling to tackle hoaxes and fake news, especially those circulated in social media. The prevalence of hoaxes and fake news has shaped a new kind of political discourse. Scholars called this Post-Truth politics: a situation in which misinformation is widespread, causing confusion and distrust (Lewandowsky, Ecker \& Cook, 2017; Corner, 2017; Suiter, 2016). Prior to 2016, the word "post-truth" was virtually unknown by the media. This all changed with the 2016 United States election, which was won by Donald Trump. At the time, American voters were swamped with hoaxes and conspiracy theories attacking both sides of the campaigns. This invalidated information primarily circulated through social media. Soon, the word became known globally, and because of its popularity, Oxford Dictionary selected "post-truth" as the word of the year 2016 (Flood, 2016).

In Indonesia, the 2017 Jakarta Gubernatorial Election was one of the pivotal moments when discussing post-truth and politics. The election saw an unprecedented exploitation of identity politics, causing division and polarization between the supporters of two candidates: Anies-Sandi and Ahok-Jarot. Rumors, gossip, hatred, and abusive comments were rampant on every social media platform, heavily disadvantaging the candidacy of Ahok who came from a minority group and minority religion. Post-Truth and identity politics have become two inseparable phenomena within Indonesian politics and many politicians seek to exploit this condition for their own benefit.

Indonesia is a country with more than 300 ethnic groups with their own language, culture and religious affiliation. For this reason, Indonesia is particularly vulnerable to the hostile play of identity politics. Many fear that conflict related to identity politics, due to the chaotic circulation of hoaxes, could lead to a Post-Democratic situation where the democratic principles such as freedom, human rights, equality and pluralism develop into an extreme practice such as absolute freedom and anarchy.

While plenty of research has been done about Post-Truth or the language of hoaxes and fake news in Indonesia (e.g. Adiwilaga et al., 2017; Sirajuddin et al., 2017; Suriadi, 2017), none has seemed to incorporate identity politics in their analysis. Seeing the gap in the current literature, this research seeks to analyze how the post-truth phenomenon incorporates the issue of identity politics in generating a Post-Democratic situation in Indonesia. To achieve this we look at two case studies: the 2017 Jakarta provincial election and the 2019 presidential election. Secondary data analysis from the news and social media will be employed to further explain how identity politics is distorted in the media, and how it can generate social and political turbulence. 


\section{Identity Politics}

There has been a marked increase in polarization within countries across the world, and some scholars attributed such development to the rise of identity politics. A common feature of this phenomenon is people no longer favoring an alliance over traditional political denominators such as class and economic background. Instead, people prioritize their concern based on a certain set of social and cultural attributes that represent themselves.

Originally, identity politics was widely used throughout the social sciences and the humanities to describe various types of activism related to politics, culture, and identity such as the civil rights movement, women's movement, and others. Anspach (1979) first used the term identity politics in her depiction of the activism by people with disabilities to empower both self- and societal conceptions of disabilities. In the following years, identity politics were used to define a political alliance or movement of a particular race, ethnicity, gender, or religion to defend their group's interests. Recent developments, however, show that identity politics can be incredibly divisive as opposing groups often become deeply entrenched in their respective identities and ignore those who do not share the same identities. And by this development, there is a risk of diminishing the public interest of the general population.

Gidron and Hall (2018) noted that there are two trends that increasingly drive divisive identity politics. First, the long term consequence of globalization, which can give rise to winners and losers. While the winners earn benefits from this development, the losers lack the opportunities to thrive and are not particularly well represented by their politicians. Secondly, there is an increasing fear from the traditionally dominant groups who have gradually lost their social status or feel threatened by progressive policies brought by modernization.

Due to its social and cultural diversity, Indonesia is a fertile ground for identity politics. After political reforms in 1998, Indonesians have greater freedom to express their primordial identity, which at first aimed to advance the political development at the regional level. Soon, however, this freedom no longer served as a nation-building tool, but as a challenge to national identity. In many cases, identity politics have been used by political elites to gain power by exploiting social conflict. In other cases, identity politics have created political turmoil caused by the reemergence of past conflicts, unresolved marginalization, and injustice; an example can be seen in what is currently happening in Papua.

In recent years, identity politics in Indonesia cannot be separated from the rise of Islamic hardliners. After the 1998 reforms, many pious Muslims started to wrestle with Islam's role in modern society. This incited a national spiritual awakening 
based on the puritanical Salafist interpretation of Islam across the nation (Chaplin, 2016). Conservative Muslims started to show more explicit signs of religiosity and embraced Arab-style devotion. This meant wearing a turban and flowing robe for men, and burqas (long, flowy garments that hide the face) for women, using Arabic names, and building Middle Eastern-style architecture. Many conservative Muslims believe that corruption brought by modern society can only be fixed by reconstituting Sharia law and a Caliphate in Indonesia (Beech \& Suhartono, 2019). At some localities in Indonesia, Sharia law in its most extreme form has been imposed, for example in the Aceh province. And these groups continue to push for the adoption of Sharia law at a national level.

In April 2010, the Indonesian Constitutional Court decided to enforce a blasphemy law that provides a court sentence for those who practice deviant religious beliefs. This was considered a severe blow to religious freedom, especially for minority religious beliefs. The blasphemy law also serves as a legal basis for government regulations that facilitate official religion-based discrimination. For example, in June 2008 the government issued a decree that ordered members of the Ahmadiyah religious community to stop all public religious activities that deviated from the principal teachings of Islam. Those who violate the decree might be punished with a maximum five years jail time (Human Rights Watch, 2017).

The blasphemy law also provided the ground for the criminalization of critics against religion, framed as defamation. The example of persecution on the base of blasphemy occurred in Tanjung Balai, North Sumatra. In July 2016, Meiliana, a 44-year-old Chinese Buddhist, was complaining about how loud the adzan (call to prayer) was. Over the next few days, however, her statement became distorted, and rumors spread that a Chinese woman wanted to "ban the adzan". This provoked mobs who ransacked at least 14 Buddhist temples in Tanjung Balai, North Sumatra, and many ethnic Chinese were forced to flee the area. Shortly after, the police arrested 19 people for their role in the riot. Eight were charged with looting, nine with malicious destruction of property and two with inciting violence. All were given oneto-four-month jail sentences. On the other hand, Meiliana was jailed for 18 months on the base of violating the blasphemy law (Tehusijarana \& Gunawan, 2018).

The case above represents an example of how identity politics can be exacerbated by hoaxes and misinformation. Controversial and provocative posts are more likely to go viral because they appeal to the emotional state of the readers and people are more inclined to "share" the content in their own social media. Some distortions of the news can easily provoke violence, because they are designed to target people's emotional, not logical, response. 


\section{Post-Truth and the Drives to Post-Democracy}

In Oxford Online Dictionaries, Post-Truth is defined as: "relating to circumstances in which people respond more to feelings and beliefs than to fact" (oxfordlearnersdictionaries.com, n.d). The term was actually first coined by Steve Tisich in his 1992 article criticizing American people who chose to believe the propaganda of the US government, especially related to the Watergate scandals and the Iran-Contra affair, because they were obsessed about their safety (Corner, 2017).

Post-Truth is closely linked to the proliferation of hoaxes and fake news. Kusman (2017) defines hoax as "false information designed to influence or provoke an audience into acting in accordance with the interests of the creator and circulated through social media". Fake news, popularized by Donald Trump, is used in an almost similar fashion as hoaxes. However, fake news has a more specific connotation as originally it was used to refuse criticism and deprecate news that conflicts with his public stance (Jay, 2010). Most of these hoaxes and fake news made their way to the public through social media.

Social media, such as Facebook, Youtube, and Instagram, operate on certain algorithms that decide which content the users will see on their screen. The algorithms are all about engagement. The more likes and comments that a post has, the post will be recommended to more people and go viral. Many of the hoaxes are produced by fake accounts, supported by paid Internet trolls and an army of automated bots created specifically to amplify posts that attack certain groups or individuals. Advertisement services are also directly available within each media to send the message and target a specific population. This is possible as the revenue for many social media platforms comes from collecting detailed and refined personal data that make it possible for advertisers to micro-target individuals (Senate Judiciary Committee, 2017).

The public tends to believe in the fake messages not because they are faced with limited information, but due to an overload in information (Paul \& Matthews, 2016). Social media allow people to publish streams of valid or invalid information very easily. People are swamped with numerous news and rumors every day that most of the public no longer want to fact-check. Cognitive dissonance theory states that when people are presented with two pieces of knowledge that are different from one another, a state of dissonance will occur (Festinger, 1957). To solve this dissonance, people will try to either remove the dissonant cognitions, add new consonant cognitions, or reduce the importance of the dissonant cognitions (Worchel et al., 2000). Furthermore, Lewandowsky et al. (2012) argue that people assess the logical compatibility of the new information with their pre-existing beliefs. Information (or misinformation) "consistent with one's worldview" is "more familiar, easier to process, 
more coherent, more supported in one's network, and more likely to be viewed as coming from a trusted source" (Ibid., p. 118). Therefore, when the new information contains no elements that contradict an individual's current knowledge, such information will be accepted without checking how factual it is. An example is seen in climate change denial. About $97 \%$ of climate scientists agree climate change is indeed happening (e.g., Anderegg et al., 2010; Cook et al., 2013). However, climate change denialists choose to believe in just a number of peer-reviewed publications or trust in non-scientific outlets such as blogs whose credibility are questionable.

An example of the most popular and successful cyber warfare strategy involving fake news was orchestrated by the Russian Government. Paul and Matthews (2016, p. 1) named this strategy the "Firehose of Falsehood" because of its two distinct features: it is "rapid, continuous, and repetitive, and it lacks commitment to consistency". In this strategy, quantity is key. The Firehose of Falsehood produced high volumes of hoaxes in the form of text, video, audio, and photos that are distributed through multiple channels, including websites, social media, television programs, and traditional radio broadcasts.

This strategy pays little attention to the credibility and the consistency of the message. The propagandist's messages can be debunked easily; however, they are incredibly quick and responsive. Not paying attention to their credibility means they can quickly use a portion of the story to create a message without worrying about its verification. It does not matter if the message is partially or completely wrong, as long as it supports their purpose. Sometimes, the message is completely fictive.

In Indonesia, the strategy was allegedly used during some of the biggest elections in the country. Prior to the election, a massive number of negative campaigns were circulating across social media platforms, especially Twitter, Facebook, Instagram, and in WhatsApp groups. The hoaxes, partial or complete lies, were formulated by supporting propagandists of both sides of the campaign, then sent to groups of supporters and "buzzers". A "buzzer" is a social media user who is paid by a company to promote certain brands on their own accounts. However, during the election, these buzzers worked to spread hoaxes that would benefit the supported candidate and discredit their opponent. During the 2017 Jakarta election, these buzzers claimed to be paid around two to four million Rupiah (USD 150-300) per month prior to election day. The spread of hoaxes was often amplified by micro-celebrities or political influencers, such as Denny Siregar or Jonru Ginting. With millions of followers on their blogs and social media platforms, their framing was often copied and then spread in WhatsApp groups where these messages were circulated and further consumed by the public (Lim, 2017).

This strategy of producing a high volume of information in multiple channels, such as Twitter, Facebook, LiveJournal, and Instagram, brings some advantages. 
First, by broadcasting messages in multiple channels, it will increase the likelihood of people seeing the messages. Second, it will overtake and rebut competing messages in a flood of disagreement. Lastly, when the messages are broadcast in multiple channels and appear to have a large amount of support, then people tend to perceive the messages as credible, especially if they can identify with one of the channels of their distribution (Hughes et al., 2014).

There is also a phenomenon which Eli Pariser (2011) named the "filter bubble". As part of its effort to personalize the experience of its users, social media algorithms often preselect what is visible to users and what is not visible to them. This was intended to help users view information relevant to their interests. However, it becomes increasingly detrimental to how people "encounter ideas and information". The invincible filter prevents people from receiving information that is contrary to what they already believe (Ibid.). This can create situations that "prohibit individuals from being properly informed and rational democratic citizens" (Haim et al., 2017, p. 4).

The whole ecosystem of hoaxes and fake news on the Internet has created a lucrative business. Data broker companies collect and sell individuals' personal data, often without the consumer knowing. This big data is obtained from all sorts of online activity, including web browsing histories, public records, online purchases, and other sources. The information is used to predict the user's personal attributes, such as location, ethnicity, political attitudes, etc. This data is valuable, not only for businesses, but also for political actors (Pinchot et al., 2018). One of the most famous data brokers is Cambridge Analytica which was believed to be responsible for Trump's election in the United States and Brexit in the United Kingdom referendum. The company usually sells data to the highest bidder and then helps their clients to gain constituents by micro-targeting social media users and influencing their decisions (Rosenberg et al., 2018).

There are also a growing number of people who manage fake news websites in exchange for a commission. These people often live far away and do not care about what is happening in the targeted country. For example, the small town Veles in Northern Macedonia hosted 140 different pro-Trump fake news websites, operated mostly by teenagers who were able to earn a significant amount of money if they were successful in spreading misinformation (Ball, 2017).

As a grand concept, Post-Truth highlights an idea that there has been a significant change in the circulation of information and it has affected the public domain (Schlesinger, 2015). It carries some heavy philosophical baggage that truth is currently seen as subjective instead of objective. Jean Baudrillard (1981) predicted this condition decades ago, calling it the world of "hyper-reality" where there are no visible boundaries between reality and non-reality. Myth, fantasy, imagination, fiction 
which used to be considered as non-reality, have now materialized because of technological advancement in computing and the Internet. This whole cyberspace ecosystem has created a manipulated reality. Namely, when reality is simulated, it can be used to cover up, obscure, and change reality. This increasingly sophisticated state of cyberspace development is the biggest factor in what is called Post-Democracy.

Piliang (2004) described the phenomenon that he called Post-Democracy. This is when the image of democracy has been completely disconnected from the real ideal framework of democracy itself. Firstly, at the surface level, Post-Democracy is full of its own simulacrum (distorted simulation), but continues to pose as if it were a real copy or icon of democracy. Second, in the world of Post-Democracy there is an overlapping occurrence of democratic principles with other principles, such as anarchism and act of freedom, both at the level of the image and the level of interaction. The concepts that build democracy itself such as pluralism, equality, human rights, freedom, voice, association, have developed to the extreme point, past the principles of democracy itself and leaning into anarchy.

This Post-Democracy situation was felt during the largest elections in Indonesia, especially during the election of the Jakarta Province (2017) and the Indonesia presidential election (2019).

\section{The Jakarta Provincial Election and the Decline of Secular Democracy}

Politics in Jakarta, as the capital city of Indonesia, has always been in the center spotlight. Securing a position as the governor of Jakarta promises constant attention from the public and media. The current President of Indonesia, Joko Widodo, was also the governor of Jakarta for two years before he decided to compete in the 2014 presidential election. No wonder many politicians are eager to compete in order to win the vote of roughly 7.7 million voters from different ethnic and religious backgrounds (The Jakarta Post, 2018). Unfortunately, the 2017 election became a black mark in the history of Indonesian politics. The election was fueled with rampant misinformation, ethnic- and religion-motivated hate speech, and violent protest.

The incumbent Governor, Basuki Tjahaja Purnama (popularly known as Ahok), is a Chinese Christian who assumed the governorship after Joko Widodo stepped down to pursue (and then win) the presidential election in 2014. Ahok's policy is generally progressive, with his emphasis on anti-corruption and fixing the city's spatial development. His leadership is controversial because of his blunt and brash manner, as seen by his firm policy of evicting illegal settlers in some of Jakarta's slums. His supporters are mostly middle class and progressive Jakartans. However, as a member of the Chinese-Christian minority group, he is at odds with Islamic hardliner groups such as the Islamic Defenders Front (Front Pembela Islam - FPI) which believes that Muslim citizens should only be led by fellow Muslims. 
The online campaigns during this election were toxic from the start. Social media was packed with hoaxes and misinformation directed against all the candidates, especially the two strongest pairs: Basuki Tjahaja Purnama - Djarot Saiful Hidayah (Ahok-Djarot) and Anies Baswedan - Sandiaga Uno (Anies-Sandi). Both Ahok-Djarot and Anies-Sandi were backed by websites that published fabricated content to discredit their opponents. The pro-Anies campaign used mainly Islamist websites to spread conservative and sectarian views which were anti-Ahok in character. The majority theme of the anti-Ahok campaign material condemned Ahok's ethnicity and religion. Ahok is often labeled using a pejorative commonly use to disparage the Chinese minority in Indonesia, such as Cina Kafir (Chinese infidel), Haram (forbidden), Maksiat (Immoral), Babi (pig) and his supporters were called Cebong (tadpole) (Lim, 2017).

On the other hand, the pro-Ahok campaign created parodies of some of the most well-known conservative Islamic websites, such as arrahmahnews.com (a parody of arrahmah.com) and voa-islamnews.com (a parody of voa-islam.com). The campaign material in these websites consisted of fabricated stories about Anies' involvement in multiple corruption cases, and his support of radical Islamist groups such as ISIS and Al-Qaeda. The pro-Ahok campaign was not short of pejorative nicknames as well. Anies, who is an Arab descendant, is often called Onta (camel) or Wan Abud (a comedic Arab-descent character from an Indonesian soap opera). Anies supporters were often called anti-Pancasila (Indonesia's ideology), berjubah (robe-wearing thugs), terrorists, ISIS supporters, bani koplak (the idiot tribe), and kaum bumi datar (flat-earth people) (Ibid.).

In the discourse of power, the use of pejorative nicknames is called labeling, a practice used to differentiate one group from its opposition, framing them as different, deviant, and a threat (Gove, 1980). Those examples show how both campaigns try to frame their opponent as a homogenous group that is lesser than their own. There is also a play of victim-perpetrator positions, in which both sides try to suggest that "we are not racists, they are the real racists" (Lim, 2017). This continuous sentiment gives them reasons to perpetuate the conflict.

The shift in the political landscape in Jakarta towards the election reached its peak when Ahok became a suspect of blasphemy after a heavily edited video of him giving a speech at Pramuka Island circulated on the Internet. He was allegedly insulting Islam by mocking his opponent who often cites a Quranic verse, Al Maidah 51, as a campaign tool. This video became viral and incited outrage among conservative Muslims. This became a great source to attack Ahok and his campaign (Wijaya, 2017).

The biggest rally occurred in December 2016 as hundreds of thousands of conservative Muslims came together in central Jakarta to demand that Ahok be arrested. 
The rally, later known as the 212 Movement (as the first rally happened on 2 December), was mobilized by several groups of Islamic hardliners: the Salafi-modernist network led by Islamist preacher Bachtiar Nasir, the Islamic Defenders Front (FPI) led by Rizieq Shihab, Wahdah Islamiyah led by Zaitun Rasmin, the Indonesian Muslims Forum (Forum Ummat Islam - FUI) led by Muhammad al-Khaththath, and Hizbut Tahrir Indonesia (HTI). Many in the crowd actually came from outside of Jakarta to show their solidarity and to "defend their religion" (Sheany, 2018). This rally flipped the table and shortly after Ahok's voter base began to dwindle, Ahok-Djarot lost the second round of the election against Anies-Sandi, fifty-seven percent to forty-three percent (The Jakarta Post, 2017).

Other than religion, there is also a complex interplay between class elements (economic inequality) and socio-cultural identity politics in Jakarta. An underlying tension between stereotypes about "rich Chinese" vs "poor Muslim pribumi" (poor Muslim native) which often instigates faction fights. Coupled with Ahok's forced eviction policies in North and East Jakarta, he is continually seen as the representation of the Chinese elite capitalists who are nonchalant towards the poor (generally Muslim natives) (Warburton \& Gammon, 2017). The final result of the election shows that Ahok's vote dwindled in poorer areas. Exit polls from Indikator Politik and Saiful Mujani Research and Consulting (SMRC) also indicated that people who earned less than 4 million Rupiahs per month were more likely to vote for Anies (Setijadi, 2017).

After the election, in the midst of intense pressure from an Islamic hardliner group, on 9 May 2017, the head judge announced that Ahok was found to have legitimately and convincingly conducted a criminal act of blasphemy (Lamb, 2017). Two years of imprisonment were imposed until he was finally freed in January 2019.

What happened in this election signifies a bigger movement currently pursued by the FPI and other Islamic hardliner groups, who aim to push the country into an outwardly Islamic identity. Ahok, a non-Muslim, for some time was a symbol of secularism and progressive politics in Indonesia. His first term appointment showed that Jakarta was initially ready to look beyond a politician's background and more at his ideas and commitment. It was exactly why Islam hardliner groups perceived him as a threat. In order to further push Indonesia's politics towards an Islam-centrist institution, it is in their interest to nominate and support political candidates for executive office who are sympathetic to Islamist objectives.

\section{Presidential Election: Identity Politics and the Simulacrum of People Power}

The Indonesia presidential election in 2019 was the biggest single day election to ever happen. The election involved around 245,000 candidates running for more 
than 20,000 national and local legislative seats across the country (BBC News, 2019). While the election covered both national and local government, the national election to elect the next President dominated the political discussion. The presidential election was joined by two old rivals, the incumbent President Joko Widodo (Jokowi) was running against retired general Prabowo Subianto.

Jokowi was a furniture entrepreneur from Central Java whose career in politics skyrocketed over the past few years. Despite being the "outsider" of the oligarchy, he won Jakarta's provincial election in 2012. He left the post as a governor only after two years in the position to run in the 2014 presidential election, which he ultimately won.

Jokowi has always been vulnerable to religion related issues. In the 2014 election, Jokowi was rumored to be a Communist, a Christian, of Chinese descent, or was actively promoting non-Muslim interests. After Ahok's fall, some of the Muslim organizations that had formed the 212 movement began to aggressively target Jokowi. In response, Jokowi has taken tough measures by backing criminal charges against Rizieq Shihab, the leader of the FPI, who was actively criticizing his government. As a result, dissatisfied Islamic conservatives formed alliances with Prabowo to push their agenda (Lindsey, 2019).

Learning from the 2017 Jakarta provincial election and hoping to increase his appeal to Muslim voters, Jokowi chose Ma'ruf Amin as his running mate. Amin was the head of the Indonesian Ulama Council, a powerful and respected traditionalist Muslim who had a key role in the protests that led to Ahok's downfall. It was a surprising decision because Jokowi is a Muslim moderate with a huge following of liberal supporters (Dewi, 2018). Adversely, Jokowi lost a significant amount of his liberal supporters. Muhammadiyah, the second largest Muslim organization, was officially neutral, but many of its members sided with Prabowo.

Prabowo is a former son-in-law of Indonesian dictator Suharto and a former general during the New Order era. The 2019 election would be his third time competing in a presidential election. He chose Sandiaga (Sandi) Uno as his running mate. Sandi won the 2017 Jakarta provincial election as the Vice Governor, but decided to leave his post for the 2019 election. He is a successful young entrepreneur and was expected to attract a younger voter base.

Starting at the beginning of 2018 , hoaxes related to the presidential election were gripping the nation. The Indonesia Ministry of Technology managed to capture 771 hoaxes or fake news stories during the 2019 election, starting from August 2018 to February 2019 (Indonesia Ministry of Technology, 2019). Both candidates said that they were victims of fake news. Jokowi was accused of being a supporter of the forbidden Communist Party, while Prabowo was suspected of supporting the caliphate or Indonesia Islamic State. Not only targeting the candidates, fake news 
also targeted Indonesia's electoral institutions, such as the General Election Commission (Komisi Pemilihan Umum - KPU) and Election Oversight Body (Badan Pengawas Pemilu - Bawaslu). This was seen as an effort to delegitimize the election process.

The 2019 election was arguably the most divisive presidential campaign in the country's recent history. As with the 2017 election in Jakarta, identity politics was the central issue during the election. It overshadowed the debate on critical topics such as economy, infrastructure, and corruption.

On 21 May 2019, the KPU announced that Jokowi was the winner of the 2019 presidential election. Jokowi-Ma'ruf won $55.5 \%$ of the vote (over 85 million votes), while Prabowo-Sandi only got 44.5\% (about 68 million votes). An exit poll done by Indonesia Political Indicators (IPI) on the election day found that non-Muslims and traditional Muslims supported Jokowi-Ma'ruf: 97 percent of non-Muslim voters voted for Jokowi-Ma'ruf, an increase of 15 percent when compared to the election five years before; 56 percent of traditional Muslims from the Nahdlatul Ulama (NU) voted for Jokowi-Ma'ruf, an increase of 12 percent compared to 2014. By contrast, Prabowo-Sandiaga won a landslide victory among Muhammadiyah, conservative Muslims, and other Muslim mass organizations. This shows that voters' choice was mainly made based on the affiliation of identity, and they made their choice long before the open campaign period began (Ristianto, 2019).

The geographical distribution follows a similar trend. Jokowi won in Javanese communities linked to the NU and in provinces where non-Muslims are a significant portion of the population, such as Papua, Bali, East Nusa Tenggara and North Sulawesi. While Prabowo won in majority Muslim outer islands often associated with Muhammadiyah, such as West Sumatra, South Sulawesi, Southeast Sulawesi, Bengkulu and Jambi (Lindsey, 2019).

Prabowo and his campaign team, however, rejected the results and claimed that they should have secured more than $60 \%$ of the vote. He further added that there were alleged "massive irregularities" in the votes with millions of fictitious names added to voter rolls, the exploitation of the state apparatus, illegal payments, precast ballots, and data entry errors by the KPU (Nurita, 2019). His claim of winning and his accusation were made repeatedly to sow confusion and distrust among his supporters.

A message to protest the election results, which Prabowo campaign called "mobilizing the people power", had been widely echoed ahead of the announcement. This call was initiated by a number of political figures in Prabowo's circle, such as Amien Rais and Eggi Sudjana (Ghaliya, 2019). This is another example of political simulacrum used during the election. The term "people power" actually means the use of mass power (people) to force political change or a change of power in a coun- 
try (April, 2012). The example of people power mobilization can be seen during the demonstration to push the resignation of President Sukarno in 1966-1967, as well as the overthrow of President Suharto in 1998. Using people power in this context is inappropriate because the movement should represent the interest of all Indonesians and not just a handful of people who act on behalf of partisan political interests.

After the results were announced by the KPU on 21 May 2019, several groups began to hold demonstrations in front of the Bawaslu office. The demonstration turned violent in the evening, with some protesters throwing stones, Molotov cocktails and large firecrackers. The riots spread to several places, in front of the Police Dormitory in West Jakarta, Slipi, Sabang and Tanah Abang area. At least 8 people died and 730 people were injured during the riots (Atika, 2019).

\section{Post-Truth in Indonesia: What Are the Ways Forward?}

Political turbulence is a natural part of democracy. As stated by Serres (1990), political turbulence in a positive sense will create dynamic political relationships, especially if there are various ideas, concepts, and dynamic political strategies among political elements. However, if this turbulence leads to a vulgar, vicious political game in the context of destabilizing political power, then the result will be political death. And when the principles of trust and truth cannot be found, what exists is the face of anarchism and chaos, full of falsehood and deviation: a condition of postdemocracy (Piliang, 2004).

The contemporary media ecosystem contributes to the creation of a Post-Democratic society. And this problem is not specific to social media alone. Currently there is very little effort from even the traditional media to fact-check stories. Real time reporting often eliminates fact-checking. Often the source of stories are some online commentaries or articles whose credibility should be questioned. Such a condition is an irony, as noted by Ball (2017, p. 10): "traditional media boosts and profits from fake news even as it tries to fight it".

More importantly, there is a lack of journalist integrity in news stations all over the world. Many of these stations operate out of a certain business model and ideological background, which then govern which issues are to be covered and how issues should be covered. Fox News, for example, relies so heavily on its republican viewer base that the news covered are often skewed depending on how it advances the right-wing agenda (Ball, 2017). Their main priority is to drive ratings even if it means sacrificing a fair and balanced assessment.

In Indonesia, the media's culture is heavily skewed depending on which candidate or which party is affiliated with the owner. Take Metro TV, for example. The station is owned by Surya Paloh, the leader of National Democratic (Nasdem) Party which is included in the coalition that supported Jokowi's candidacy in 2019. 
The news coverage on the network dominantly highlights Jokowi's achievement and rebuts any attacks from his opponent. This way Metro TV acts as a media buffer for the coalition in order to secure a significant number of voters from its viewers.

In Indonesian society, which has arguably seen a near instant introduction and development of information technology, various critical sides of this development will clearly have a more adverse effect on the development of the society itself. In what Piliang (2004) called an information society, every person is required to have the ability to analyze the information critically, compare various pieces of existing information, and make rational decisions. The weak analytical power of Indonesian society has caused it to be trapped in a digital public space where the political elites' fight for their ideas, ideology, and interest are in the abstract. As a result, people are caught in disinformation and conflict scenarios created by these elites. In addition, traits such as emotionality, selfishness, tribal sentiments, religious sentiments add additional fuel to this fire. This further prevents people from conducting rational debates and constitutes a major obstacle to the process of dialogical democratization.

Furthermore, a superficial understanding of the principle of democracy creates numerous interpretations about democracy that are distorted or even completely wrong (Ibid.). Democracy is often interpreted as total freedom, total autonomy, and basically doing whatever is desired. This has led to the development of social dynamics that are at odds with the concept of democracy itself. Anarchist actions such as the burning of public infrastructure and unwarranted attacks against police, are the manifestation of a distorted democratic understanding.

Several solutions can be proposed in dealing with the negative turbulence in politics by making various changes to some aspects of democracy itself (Ibid.). The first is change at the symbolic level. The confusion of information, data distortion, disinformation, dramatization, or symbolic extremism must be stopped. The government must establish control over the flow of information within the society by filtering disinformation and notifying people of hoaxes in circulation.

Second, at the normative level, by targeting the law. The gray boundary between truth and falsehood, between information and disinformation must be able to be defined and confirmed within the law. It also includes adding a specific penal code for the producer and circulator of hoaxes.

Third, changes in the level of political discourse. Turbulence at the level of political discourse, political communication, and socio-political interaction, which causes the blocking of communication channels between elements of the state and society must be transformed into a more dynamic and constructive form of discourse.

Fourth, changes at the cultural level. Cultural attitudes that center on egocentrism and identity centrism must be taken over by attitudes that prioritize society at 
large (socio-centrism). The turbulence that has occurred must be seen and directed as lessons for the future to create a more positive democratic culture.

In general, improvements need to be made at various levels. The government must be able to translate the social and political simulacrum which many see as democratic processes into real democracy. When the community has been given the basic ability to filter the social and political simulacrum from true and constructive information, chaos resulting from the marriage of identity politics and Post-Truth can be successfully minimized.

\section{Conclusion}

The election of the Jakarta Province (2017) and the Indonesian presidential election (2019) have revealed the Post-Democratic situation in Indonesia. When the concept of democracy is driven to the extreme, what we have is the face of anarchism and chaos full of falsehood and deviations from democratic norms.

The current media ecosystem has an enormous role in the making of this phenomenon. Social media platforms have become a place where hoaxes and fake news circulate freely with very little repercussion for their perpetrators. In traditional media, the trend of real time reporting has often eliminated fact-checking. Distorted and unchecked news circulates among the people, further exacerbating confusion and mistrust, even provoking violence because they are made to target people's emotional, and not their logical response.

Several solutions need to be implemented in order to solve the problem caused by Post-Truth politics by making changes to some aspects of democracy itself. The government needs to regain control and provide notification to the people of dangerous hoaxes and fake news circulating in the society. Lastly, people need to increase their critical ability in receiving, filtering and accepting information and to always consult those trusted media channels that have a reliable reputation.

\section{REFERENCES}

Adiwilaga, R., Ridha, M. \& Mustofa, M. (2017). Pemilu dan Keniscayaan Politik Identitas Etnis di Indonesia: Sebuah Tinjauan Teoritis. Jurnal Bawaslu, 3 (2): 269-284.

Anderegg, W. R. L., Prall, J. W., Harold, J. \& Schneider, S. H. (2010). Expert credibility in climate change. Proceedings of the National Academy of Science (PNAS), 107 (27): 12107-12109. DOI: https://doi.org/10.1073/pnas.1003187107.

Anspach, R. (1979). From stigma to identity politics: political activism among the physically disabled and former mental patients. Soc. Sci. Med., 13A: 765-773. 
April, C. (2012). People Power and Political Change: Key Issues and Concepts. Routledge. London \& New York.

Atika, S. (2019). Jakarta riots death toll rises to eight, more than 700 injured. Available at: https://www.thejakartapost.com/news/2019/05/23/jakarta-riots-death-toll-risesto-eight-more-than-700-injured.html

Ball, J. (2017). Post-Truth: How Bullshit Conquered the World. Biteback Publishing. London.

Baudrillard, J. (1981). Simulations. Semitext(e). New York.

BBC News. (2019). Indonesia election 2019: All you need to know. Available at: https:// www.bbc.com/news/world-asia-47729119

Beech, H. \& Suhartono, M. (2019). Faith Politics on the Rise as Indonesian Islam Takes a Hard-Line Path. Available at: https://www.nytimes.com/2019/04/15/world/asia/ indonesia-election-islam.html

Chaplin, C. (2016). Global Salafi Activism and Indonesian Islam. Available at: https:// www.newmandala.org/global-salafi-activism-indonesian-islam/

Cook, J., Nuccitelli, D., Green, S. A. (2013). Quantifying the consensus on anthropogenic global warming in the scientific literature. Environmental Research Letters, 8: 024024. DOI: 10.1088/1748-9326/8/2/024024

Corner, J. (2017). Fake news, post-truth and media-political change. Media, Culture \& Society, 39 (7): 1100-1107.

Dewi, S. W. (2018). Who is Ma'ruf Amin, Jokowi's running mate?. Available at: https:// www.thejakartapost.com/news/2018/08/09/who-is-maruf-amin-jokowis-runningmate.html

Festinger, L. A. (1957). A theory of cognitive dissonance. Row, Peterson. Evanston, IL.

Flood, A. (2016). 'Post-Truth' named word of the year by Oxford Dictionaries. Available at: https://www.theguardian.com/books/2016/nov/15/post-truth-named-wordof-the-year-by-oxford-dictionariesFoster

Ghaliya, G. (2019). Public figures hearten KPU following 'people power' threat. Available at: https://www.thejakartapost.com/news/2019/04/10/public-figures-heartenkpu-following-people-power-threat.html

Gidron, N. \& Hall, P. A. (2018). Populism as a Problem of Social Integration. Available at: https://scholar.harvard.edu/...les/hall/...les/gidronhallmay2018.pdf

Gove, W. R. (1980). Labeling of deviance: evaluating a perspective. Sage Publications. Beverly Hills.

Haim, M., Graefe, A. \& Brosius, H.-B. (2017). Burst of the Filter Bubble?: Effects of personalization on the diversity of Google News. Digital Journalism: 1-14.

Hughes, M. G., Griffith, J. A., Zeni, T. A., Arsenaut, M. L., Cooper, O. D., Johnson, G., Hardy, J. H., Connelly, S., Muford, M. D. (2014). Discrediting in a Message Board 
Forum: The Effects of Social Support and Attacks on Expertise and Trustworthiness. Journal of Computer-Mediated Communication, 19 (3): 325-341.

Human Rights Watch. (2017). Indonesia: 'Religious Rights' Bill Would Harm Minorities. Available at: https://www.hrw.org/news/2017/07/20/indonesia-religious-rights-billwould-harm-minorities

Indonesia Ministry of Technology. (2019). Kominfo Jaring 771 Konten Hoax, Mayoritas Terkait Politik. Available at: https://kominfo.go.id/content/detail/17071/kominfojaring-771-konten-hoax-mayoritas-terkait-politik/0/sorotan_media

Jay, M. (2010). The Virtues of Mendacity: On Lying in Politics. University of Virginia Press. Charlottesville.

Kusman, A. P. (2017). Hoaxes and fake news: a cancer on Indonesian democracy. Indonesia at Melbourne. Available at https://indonesiaatmelbourne.unimelb.edu.au/ hoaxes-and-fake-news-a-canceron-indonesian-democracy/

Lamb, K. (2017). Jakarta governor Ahok sentenced to two years in prison for blasphemy. Available at: https://www.theguardian.com/world/2017/may/09/jakarta-governorahok-found-guilty-of-blasphemy-jailed-for-two-years

Lewandowsky, E., Ecker, A. K. \& Cook, A. (2017). Beyond Misinformation: Understanding and Coping with the "Post-Truth" Era. Journal of Applied Research in Memory and Cognition, 6: 353-369.

Lewandowsky, S., Ecker, U. K. H., Seifert, C. M., Schwarz, N. \& Cook, J. (2012). Misinformation and its correction: Continued influence and successful debiasing. Psychological Science in the Public Interest, 13 (3): 106-131.

Lim, M. (2017). Freedom to hate: social media, algorithmic enclaves, and the rise of tribal nationalism in Indonesia. Critical Asian Studies, 49 (2): 411-427.

Lindsey, T. (2019). Jakarta riots reveal Indonesia's deep divisions on religion and politics. Available at: https://theconversation.com/jakarta-riots-reveal-indonesias-deepdivisions-on-religion-and-politics-117818

Nurita, D. (2019). 8 Poin Prabowo saat Bertemu Media Asing, Bicara Kecurangan Pemilu. Available at: https://nasional.tempo.co/read/1202718/8-poin-prabowosaat-bertemu-media-asing-bicara-kecurangan-pemilu

oxfordlearnersdictionaries.com. (n.d.). Post-Truth. Available at: https://www.oxfordlearnersdictionaries.com/definition/english/post-truth?q=post-truth

Pariser, E. (2011). The Filter Bubble: What The Internet Is Hiding From You. Penguin Books. New York.

Paul, C. \& Matthews, M. (2016). The Russian "Firehose of Falsehood" Propaganda Model. Available at: https://www.rand.org/pubs/perspectives/PE198.html

Piliang, Y. A. (2004). Posrealitas: Realitas Kebudayaan dalam Era Posmetafisika. Yogyakarta. Jalasutra. 
Pinchot, J., Chawdhry, A. A. \& Paullet, K. (2018). Data Privacy Issues in the Age of Data Brokerage: an Exploratory Literature Review. Issues in Information Systems, 19 (3): 92-100.

Ristianto, C. (2019). Politik Identitas Dianggap Sebagai “Winning Template” di Pilpres 2019. Available at: https://nasional.kompas.com/read/2019/05/29/20001181/politik-identitas-dianggap-sebagai-winning-template-di-pilpres-2019

Rosenberg, M., Confessore, N. \& Cadwalladr, C. (2018). How Trump Consultants Exploited the Facebook Data of Millions. Available at: https://www.nytimes. com/2018/03/17/us/politics/cambridge-analytica-trump-campaign.html

Schlesinger, P. (2015). The Media and Public Life: A History. Polity Press. Cambridge.

Senate Judiciary Committee. (2017). Comittee on the Judiciary. Available at: https:// www.judiciary.senate.gov/download/10-31-17-stretch-testimony

Serres, M. (1990). Conversations on Science Culture and Time. The University of Michigan Press. Michigan.

Setijadi, C. (2017). Ahok's Downfall and the Rise of Islamist Populism in Indonesia. Perspective, 8 June.

Sheany. (2018). Understanding the 212 Movement. Available at: https://jakartaglobe.id/ context/understanding-212-movement

Sirajuddin, Kamil S. U. R. \& Fachruddin, S. (2017). War 3.0: The Indonesia Challenge Against Hoax, Hate Speech and Social Media Abuse. Advances in Social Science, Education and Humanities Research (ASSEHR), 143: 88-90.

Suiter, J. (2016). Post-Truth Politics. Political Insight, December: 25-27.

Suriadi, M. A. (2017). The Language of Hoax: Explosive Growth of Fake News in the Biggest Muslim Society. Advances in Social Science, Education and Humanities Research, 302: 75-78.

Tehusijarana, K. M. \& Gunawan, A. (2018). The Meiliana Case: How a noise complaint resulted in an 18-month jail sentence. Available at: https://www.thejakartapost.com/news/2018/08/23/the-meiliana-case-how-a-noise-complaint-resulted-inan-18-month-jail-sentence.html

The Jakarta Post. (2017). Anies beats Ahok in runoff vote: Quick counts. Available at: https://www.thejakartapost.com/news/2017/04/19/anies-beats-ahok-in-runoffvote-quick-counts.html

The Jakarta Post. (2018). Jakarta voter list rises to 7.7 million. Available at: https:// www.thejakartapost.com/news/2018/12/14/jakarta-voter-list-rises-to-7-7-million. html

Warburton, E. \& Gammon, L. (2017). Class dismissed? Economic fairness and identity politics in Indonesia. Available at: https://www.newmandala.org/economic-injustice-identity-politics-indonesia/ 
Wijaya, C. A. (2017). Ahok's speech not blasphemous: Expert. Available at: https://www. thejakartapost.com/news/2017/03/21/ahoks-speech-not-blasphemous-expert.html

Wong, E. (2019). How Indonesians embrace the digital world. Available at: https://www. thejakartapost.com/academia/2019/03/18/how-indonesians-embrace-the-digitalworld.html

Worchel, S., Cooper, J., Glethals, G. R. \& Olson, J. M. (2000). Social psychology. Wadsworth Thomson Learning. Stamford.

Mailing Addresses:

Made Yaya Sawitri, Faculty of Social and Political Science, Warmadewa University, Terompong St, East Denpasar, Bali, Indonesia.

E-mail: yayasawitri@gmail.com

I Nyoman Wiratmaja, Faculty of Social and Political Science, Warmadewa University, Terompong St, East Denpasar, Bali, Indonesia.

E-mail: inyomanwiratmaja@gmail.com 